\title{
Aid-Growth Nexus in South Asia: Evidence from Time Series and Panel Cointegration
}

\author{
Murshed Chowdhury (Corresponding author) \\ Department of Economics, University of Manitoba \\ 501-15 Chancellors Circle, Winnipeg, Manitoba, R3T 5V5, Canada \\ Tel: 1-204-269-7934 E-mail: umchowdm@cc.umanitoba.ca \\ Anupam Das \\ Department of Policy Studies, Mount Royal University \\ 4825 Mount Royal Gate SW, Calgary, Alberta, T3E 6K6, Canada \\ Tel: 1-403-440-6535_E-mail: adas@mtroyal.ca
}

\begin{abstract}
Given the strong likelihood of a sharp decline in remittance flows because of the recent recession, coupled with limited access to the global capital market, foreign aid inflow in South Asia can play an important role in boosting economic growth in this region. In the existing literature, the relationship between foreign aid and per capita real GDP is rather inconclusive. Does aid work in South Asia? We answer this question for five economies in this region: Bangladesh, India, Nepal, Pakistan, and Sri Lanka. Using both country-specific time series and a recently developed panel cointegration procedure over the period 1976 to 2008 , our results suggest a positive long run relationship between growth rate of per capita real GDP and aid as a percentage of GDP for four out of five countries. Hence, this investigation tends to support the aid effectiveness hypothesis for South Asian countries.
\end{abstract}

Keywords: Foreign aid, Growth, South Asia, Cointegration 


\section{Introduction}

Foreign aid is an important source of foreign capital in developing countries (Chenery and Strout, 1966, Pallage and Robe, 2003, Hatemi-J and Irandoust, 2005). Given the strong likelihood of a sharp fall in remittance flows because of the recent recession, coupled with limited access to the global capital market, foreign aid can play a significant role in boosting economic growth in developing regions. In the existing literature, the relationship between aid inflows and economic growth is far from unanimous. Critics like Friedman (1958) and Bauer (1971) argued that foreign aid would create dependence in developing countries by stalling the process of institutional development that was indeed important for economic development (Azam et al., 1999). Despite large inflow of foreign aid in South Asia in recent decades, widespread poverty has still been present in this region (Radelet, 2006). On the other hand, proponents of foreign aid found positive and significant relationship between aid and economic growth (Levy, 1988, Gounder, 2001). Does aid work in South Asia? Empirical studies that include South Asian countries could not produce any conclusive results. For example, Dhakal et al. (1996) failed to find any relationship between aid and economic growth in India, Nepal and Pakistan. Otim (1996), however, implicitly observed a positive relationship between aid and growth through government fiscal behavior in three South Asian countries. The apparent failure for observing any clear link between aid and growth may be attributed to several factors including small set of sample and mis-specified model that limit the effectiveness of these studies. Hence, inconclusive results on aid-growth relationship in South Asia demand for further investigation.

The aim of this paper is to shed light on the effectiveness of foreign aid on economic growth in South Asia. More specifically, an attempt is made to ascertain whether there is any link between foreign aid and per capita real GDP in five South Asian countries- Bangladesh, India, Nepal, Pakistan and Sri Lanka. This is done in four steps. We first conduct country-specific, disaggregated unit root tests. Based on these results, a disaggregated time-series cointegration approach, developed by Johansen (1991) is employed. In the third step, we conduct different unit root tests for a dynamic heterogeneous panel suggested by Im et al. (2003), Levin et al. (2002), and Maddala and Wu (1999). We find that variables under consideration are cointegrated. Therefore, we use the Error Correction Model (ECM) to identify the short run adjustment of variables towards the long run equilibrium. Finally, we undertake a panel cointegration procedure, developed by Pedroni (1999), to allow greater flexibility in the presence of heterogeneity and coningrating vectors.

In that regard, the motivation, context and results of this paper are presented as follows. Section 2 presents the theoretical and empirical background to this research. Section 3 outlines both theoretical and econometric methodology to be used to derive relevant results. Section 4 presents those results and section 5 concludes the paper.

\section{Effectiveness of Aid: A Literature Review}

\subsection{Theoretical Perspective}

Early studies considered aid as a net increment to the capital stock of the recipient country. 
Thus, aid could be used to remove the so called "savings constraint" of the original Harrod-Domar model (Papanek 1972, Newlyn 1973). This assumption of Harrod-Domar model was expanded in the influential Chenery and Strout (1966) two-gap model (the so-called first generation model of foreign aid), which aimed in explaining the significant importance of foreign aid in achieving economic growth in developing countries. They argued that in attempting to increase the economic growth, developing countries were likely to face not only a savings constraint, but also a foreign exchange constraint. Foreign aid could remove either constraint by providing required foreign exchange to developing countries. An explicit assumption of this model is that all aid is used to increase the capital stock (Chenery and Strout, 1966, Hansen and Tarp, 2000). Bacha (1990) appended this model of aid effectiveness by discussing the possibility of a third gap (in addition to savings and foreign exchange gaps) - the fiscal gap that might limit the growth prospects of developing countries. Needless to say, the basic argument that all aid was used as a net increment to the capital stock also remained the most crucial assumption in all these literatures.

Rahman (1967), Griffin (1970), Griffin and Enos (1970) and Weisskopf (1972) rather shared a skeptical view on the effectiveness of aid. This group of economists argued that if the cost of foreign resources (in the form of concessional loan and grant aid) is lower than the marginal rate of return, these resources would be preferred substitutes for domestic resources (savings). Foreign aid would then be used to displace domestic savings; hence, more domestic consumption would be encouraged in aid-recipient country. Therefore, foreign aid might not affect growth through accumulation of physical capital.

The precise role of foreign aid in generating economic growth is not immediately clear in the theoretical literature. Therefore, empirical investigations were essential to establish the aid-growth nexus in recipient developing countries.

\subsection{Empirical Literature on Aid-Growth Relationship}

\subsubsection{An Overview of Empirical Literature}

A large set of empirical research has been undertaken to estimate the growth effect of foreign aid. In a review of the empirical literature on aid-growth relationship, Hansen and Tarp (2000) made a general conclusion that aid spurred growth in developing countries. Hansen and Tarp reviewed 72 studies that estimated aid-growth relationship. 40 out of those 72 studies showed a positive relationship between foreign aid and economic growth while 31 studies did not find any significant impact. Only one study showed a negative aid-growth nexus. Hansen and Tarp also claimed that such positive impact of aid came through increased savings. Thus, it can be argued that foreign aid helps to increase economic growth in developing countries by relieving the savings constraint. Additionally, Hansen and Tarp (2000) reviewed a set of 32 regressions where aid has no significant impact on savings. However, 23 out of those 32 regressions found a significant link between aid and growth. Within the two-gap model this observation (that the growth effect of aid does not come through the savings channel) is not surprising. Hansen and Tarp (2000, pp: 385) went on arguing: 
"The observation that aid does not increase savings is not a puzzle within the two-gap model. In a two-gap model where the economy is foreign exchanged constrained there would be no relationship between aid, savings, and growth. However, aid would still be effecting in furthering growth by relieving the import constraint."

Other studies that are not covered by Hansen and Tarp (2000) but show a positive aid-growth relationship include Mbaku (1993), Giles (1994), Vasudeva et al. (1994), Gounder (2001), Irandoust and Ericsson (2005) and Burke and Ahmadi-Esfahani (2006). Several factors such as data limitation problem and mis-specified model pose a limit on the usefulness of most of these studies. Loxley and Sackey (2008) included policy variables in their growth equation to estimate the third generation models of aid effectiveness in 40 African countries. They observed that aid was positively related to growth via investment. Growth in those countries was mostly financed by aid, workers' remittances, debt service resources and domestic savings. While this is an interesting approach, time series data on policy variables are not readily available for South Asian countries.

Negative effect of aid on economic growth was predicted by Mallik (2008). Mallik investigated long run and short run relationship between foreign aid and log of real GDP per capita in six Sub-Saharan countries with lower real per capita GDP. These countries were Central African Republic, Malawi, Mali, Niger, Sierra Leone and Togo. Five out of six countries had a significant and negative long run effect of aid on economic growth. In the short run, foreign aid seemed to have no significant impact on growth of real GDP per capita in most of these Sub-Saharan economies except Niger.

\subsubsection{Empirical Literature on South Asian Countries}

While a large set of literature attempts to identify the aid-growth relationship, very few examine this issue for South Asian countries. Using time series data from 1972 to 1988, Islam (1992) suggested a weak positive relationship between aid and growth in Bangladesh. Although grants and food aid were found to be more effective than community and project aid; however, in general, foreign resources seemed to have less impact on growth compared to domestic resources. This conclusion deserves careful consideration for two reasons. First, the time period in Islam's study was short for time series analysis and second, Islam himself mentioned that estimated coefficients suffered from collinearity and specification problem.

Khan and Rahim (1993) focused on the effectiveness of aid in increasing GNP growth in Pakistan from 1960 to 1988. Although aid did not have immediate impact on GNP growth; one year lagged value of aid variable produced positive and significant growth impact. These results contradicted with Shabbir and Mohammed (1992) who earlier found a positive aid-growth relationship in Pakistan. According to Mahmood (1993), insignificant results of Khan and Rahim (1993) might be due to mis-specification of their model. Another paper by Dhakal et al. (1996) examined three South Asian countries: India, Nepal and Pakistan. Applying Granger Causality test in these countries for the period 1960 to 1990, results were inconclusive. Growth effect of aid was found to be positive and significant in India and Pakistan. 
A recent paper by Asteriou (2009) used a panel dataset for five South Asian countries to investigate the aid-growth relationship. Using both panel Mean Group (MG) and Pooled Mean Group (PMG) approaches, Asteriou found a positive aid-growth relationship in this region. This paper has done a good job in filling the gap in the existing literature that focuses mainly on cross-section analysis. This panel technique (i.e. PMG) originated by Pesaran et al. (1999) and applied by Asteriou (2009) is suited for a heterogeneous panel with large $T$ and $N$. In their seminal paper, Pesaran et al. (1999) applied the PMG techniques in two different examples. In the first example, $N=24$ and $T=32$ and in the second example, $N=10$ and $T=17$. Moreover, Blackburne III and Frank (2007), who introduced the STATA command "xtpmg" to use the PMG technique also argued that the technique would be suitable for estimating nonstationary heterogeneous panels where number of countries $(N)$ and number of time-series observations (T) are both large. It should be noted that the $N$ in Asteriou (2009) is only 5. MG and PMG analyses for small number of countries are likely to produce results which are not robust.

Our approach to estimate aid-growth relationship in South Asia is different from Asteriou (2009) in many ways. First, from a theoretical ground, our model is an estimation of a modified version of the Harrod-Domer growth model where economic growth is assumed to be determined by investment and foreign aid. We also include a trade variable to capture the effect of openness on economic growth. On the other hand, Asteriou estimated a neo-classical growth model where economic growth was determined by investment, growth in labor force and foreign aid. Subsequently, to avoid the problem of having a small $N$ and possible non-robust results, we have used both time series and panel cointegration techniques to investigate the aid growth relationship in five South Asian countries. Sensitivity analysis of the model is conducted to check the robustness of our results. Results suggest that our model is insensitive to the small changes of time period. Finally, our results also have some policy implications that are presented in the last section. To our knowledge, this investigation on aid-growth relationship using both country-specific time series and panel cointegration is unique.

\section{Methodology}

\subsection{Empirical Model and Data Issue}

Following Chenery and Strout (1966), Bacha (1990) and Mallik (2008), we also assume that foreign aid can supplement domestic savings and could be directed towards investment. Therefore, our empirical model represents the extended version of the first generation model of aid effectiveness. Nevertheless, in the reality, all foreign aid may not be used as a net increment of investment in developing countries. Aid also flows to these countries due to humanitarian reasons (Mallik 2008). To capture the specific impact of foreign aid on investment, we deduct technical assistance and food aid from the total net official development assistance (ODA). Therefore, in our data, aid represents the part of net ODA that is not given on humanitarian ground.

The second gap, i.e. the foreign exchange constraint or the trade balance gap, arises due to countries' inability to generate sufficient foreign exchange to import intermediate goods that is necessary to achieve desired level of investment. Most of the countries in South Asia suffer from insufficient export earnings to meet their import demand. Therefore, it is assumed that aid 
recipient countries would use foreign aid to import capital goods. The third constraint, i.e. the fiscal gap is an important constraint for many South Asian countries as revenue expenditures in these countries tend to exceed revenue earning. Foreign aid is used to fill this gap. While at least theoretically aid can affect growth by filling these gaps in developing countries, existing studies on South Asia do not provide a clear answer to this question. This discussion is most appropriately prefaced by the synopsis of the empirical results which follows.

Following the underlying theory, to observe the link between aid and GDP, we employ both time series as well as panel estimation procedures. While time series estimation is a better procedure for individual country analysis, panel estimation procedure is often a powerful tool as it pools estimates from a number of separate series and then tests the pooled value (Im et al., 2003).

This study considers four major variables, real GDP per capita $(p c g d p)$, foreign aid as a percentage of GDP (aidy), gross capital formation as a percentage of GDP (capy) and trade openness (exports plus imports) as a percentage of GDP (tray). All these variables are expressed in natural logarithmic term. The annual data for the period 1976 to 2008 are obtained from the World Development Indicators, International Financial Statistics and OECD database published by the World Bank, International Monetary Fund and Organization of Economic Cooperation and Development (OECD) respectively.

Our data set (both time series and panel) could be categorized as having a large T. In this context, non-stationarity of the variables becomes an issue. Secondly, a primary focus of this paper is the long-run relationship between aid and economic growth. Determining this relationship requires an estimation procedure that distinguishes between the short and long-run determinants of the growth rate- making a cointegration procedure the most appropriate estimation approach. Moreover, the problem of reverse causality (due to a high correlation between low growth and high aid flows) is also addressed by our estimation approach. Cointegration analysis supports a flexible functional form for modeling the behavior of the variables under long-run equilibrium condition. The modeling is appealing as it treats all variables as endogenous; it avoids the arbitrary choice of the dependent variable in the cointegrating equation.

If the non-stationary variables are found to be cointegrated, Error Correction Model (ECM) can be used to identify the short-run relationships among variables. The cointegration term, i.e. the error correction term will indicate the speed of short-term adjustment. The larger are the speed of adjustment parameters the greater is the convergence rate towards the long-run equilibrium.

\subsubsection{Time Series Unit Root}

Macroeconomic variables are often characterized by "random walk" (this period's value equal to last period's value plus a random walk), which makes most variables nonstationary (i.e. variables possess unit roots). To verify this hypothesis, we employ Augmented Dickey Fuller (ADF) and Phillips-Perron (PP) tests and estimate three different specifications (i.e., random walk with drift and trend, random walk with drift, and pure random walk model). All three possible specifications of the unit root test are estimated to ensure non-stationarity of all 
variables. The test results proof the presence of unit root. Finally, we also test whether the variables are difference stationary. Results of random walk with drift and trend (C\&T), and random walk with drift (C) for both $\mathrm{ADF}$ and PP tests are presented in Table 1. Results suggest that lnpcgdp and lntray contain unit root for all countries. At least one test confirms the existence of unit root for lncapy for all countries. Finally, at least one test confirms that lnaidy contains the unit root for all countries but Pakistan. One possible explanation of this inconclusive result could be the presence of structural breaks in time series variables (Perron, 1989). To test this hypothesis, we perform the "additive outlier" (AO) model (allowing for a possibility of a sudden change) and the "innovative outlier" (IO) model (appropriate for modeling a gradual shift in the mean of a series). The test statistics do not require a priori knowledge of the breakpoint, as their computation involves a two-dimensional grid search for breakpoints over the sample. Results (not presented in the paper due to the space limitation) suggest the presence of unit root when allowing for structural breaks for most of the series for all countries. Hence, we assume that most of the variables under consideration are I(1) and therefore, needs to be differenced once to obtain a set of stationary random variables. Additional results suggest that variables are stationary in first difference (See Table 1). However, such differencing procedure ignores information about long-run.

Table 1. Time Series Unit Root Tests

\begin{tabular}{|c|c|c|c|c|}
\hline \multirow[t]{2}{*}{ Variables } & \multicolumn{2}{|c|}{ ADF Test } & \multicolumn{2}{|c|}{ PP Test } \\
\hline & $\mathrm{C}$ & C\&T & $\mathrm{C}$ & C\&T \\
\hline \multicolumn{5}{|c|}{ Bangladesh } \\
\hline Lnpcgdp & 5.131 & 1.150 & 5.606 & 1.354 \\
\hline$\Delta \ln p c g d p$ & -0.378 & $-6.046^{* * *}$ & $-3.454^{* * *}$ & $-6.162^{* * *}$ \\
\hline Lncapy & -1.561 & -3.056 & -2.377 & $-5.868^{* *}$ \\
\hline$\Delta l n c a p y$ & $-3.757^{* * *}$ & $-3.881^{* * *}$ & $-15.044^{* * *}$ & $-16.256^{* * *}$ \\
\hline Lnaidy & -1.257 & $-3.488^{*}$ & -1.146 & $-3.488^{* *}$ \\
\hline$\Delta$ lnaidy & $-6.875^{* * *}$ & $-6.856^{* * *}$ & $-7.019^{* * *}$ & $-7.002^{* * *}$ \\
\hline Lntray & -0.810 & -3.039 & -0.410 & -3.033 \\
\hline$\Delta$ lntray & $-7.548^{* * *}$ & -7.547 & $-8.096^{* * *}$ & $-8.101^{* * *}$ \\
\hline \multicolumn{5}{|c|}{ India } \\
\hline $\operatorname{lnpcgdp}$ & 3.268 & -0.559 & 4.304 & -0.2023 \\
\hline$\Delta \ln p c g d p$ & $-4.707^{* * *}$ & $-6.165^{* * *}$ & $-4.728^{* * *}$ & $-6.589^{* * *}$ \\
\hline lncapy & -0.353 & -2.140 & 0.4567 & -2.136 \\
\hline$\Delta l n c a p y$ & $-7.860^{* * *}$ & $-8.044^{* * *}$ & $-7.970^{* * *}$ & $-8.210^{* * *}$ \\
\hline lnaidy & -1.380 & $-3.724^{* *}$ & -1.202 & $-3.750^{* *}$ \\
\hline$\Delta$ lnaidy & $-6.792^{* * *}$ & $-6.740^{* * *}$ & $-15.315^{* * *}$ & $-18.836^{* * *}$ \\
\hline lntray & 1.036 & -0.849 & 1.035 & -0.840 \\
\hline$\Delta$ lntray & $-4.931^{* * *}$ & $-5.336^{* * *}$ & $-4.938^{* * *}$ & $-5.334^{* * *}$ \\
\hline
\end{tabular}


Table 1 (cont.). Time Series Unit Root Tests

\begin{tabular}{|c|c|c|c|c|}
\hline \multirow[t]{2}{*}{ Variables } & \multicolumn{2}{|c|}{ ADF Test } & \multicolumn{2}{|c|}{ PP Test } \\
\hline & $\mathrm{C}$ & C\&T & $\mathrm{C}$ & C\&T \\
\hline \multicolumn{5}{|c|}{ Nepal } \\
\hline $\ln p c g d p$ & 0.5469 & -2.253 & 0.283 & -2.639 \\
\hline$\Delta \operatorname{lnpcgdp}$ & $-6.284^{* * *}$ & $-6.313^{* * *}$ & $-7.414^{* * *}$ & $-7.438^{* * *}$ \\
\hline lncapy & -2.027 & -2.383 & -2.027 & -2.971 \\
\hline$\Delta l n c a p y$ & $-7.784^{* * *}$ & $-7.664^{* * *}$ & $-8.322^{* * *}$ & $-8.208^{* * *}$ \\
\hline lnaidy & -2.452 & $-4.296^{*}$ & -2.685 & $-4.354^{* *}$ \\
\hline$\Delta l$ lnaidy & $-6.493^{* * *}$ & $-7.100^{* * *}$ & $-6.447^{* * *}$ & $-7.442^{* * *}$ \\
\hline lntray & -1.953 & -0.864 & -1.873 & -1.258 \\
\hline$\Delta$ lntray & $-4.344^{* * *}$ & $-4.472^{* * *}$ & $-4.352^{* * *}$ & $-4.486^{* * *}$ \\
\hline \multicolumn{5}{|c|}{ Pakistan } \\
\hline $\operatorname{lnpcgdp}$ & -1.323 & -1.632 & -1.190 & -1.449 \\
\hline$\Delta \operatorname{lnpcgdp}$ & $-4.156^{* * *}$ & $-4.253^{* *}$ & $-4.182^{* * *}$ & $-4.267^{* *}$ \\
\hline lncapy & -1.884 & -1.843 & -1.884 & -2.040 \\
\hline$\Delta$ lncapy & $-5.281^{* * *}$ & $-5.256^{* * *}$ & $-5.277^{* * *}$ & $-5.256^{* * *}$ \\
\hline lnaidy & -2.368 & -2.503 & -2.459 & $-4.393^{*}$ \\
\hline$\Delta \operatorname{lnaidy}$ & $-6.317^{* * *}$ & $-6.421^{* * *}$ & $-10.942^{* * *}$ & $-16.718^{* * *}$ \\
\hline lntray & $-2.738^{*}$ & -2.909 & -2.600 & -2.724 \\
\hline$\Delta$ lntray & -5.020 & -4.980 & $-5.866^{* * *}$ & $-6.516^{* * *}$ \\
\hline \multicolumn{5}{|c|}{ Sri Lanka } \\
\hline Lnpcgdp & 1.530 & -0.927 & 1.340 & -1.333 \\
\hline$\Delta \operatorname{lnpcgdp}$ & $-4.342^{* * *}$ & $-4.475^{* * *}$ & $-4.357^{* * *}$ & $-4.497^{* * *}$ \\
\hline Lncapy & $-3.333^{* *}$ & -2.427 & $-2.815^{*}$ & -2.492 \\
\hline$\Delta$ lncapy & $-4.055^{* * *}$ & $-3.931^{* *}$ & $-4.725^{* * *}$ & $-4.728^{* * *}$ \\
\hline Lnaidy & -1.053 & -2.916 & -1.637 & -2.863 \\
\hline$\Delta$ lnaidy & $-7.278^{* * *}$ & $-7.511^{* * *}$ & $-7.148^{* * *}$ & $-7.341^{* * *}$ \\
\hline Lntray & -1.910 & -2.580 & -2.126 & -1.928 \\
\hline$\Delta$ lntray & $-4.481^{* * *}$ & $-4.592^{* * *}$ & $-4.481^{* * *}$ & $-4.594^{* * *}$ \\
\hline
\end{tabular}

Notes: 1) ${ }^{* * *}, * *$ and $*$ imply significance levels at $1 \%, 5 \%$ and $10 \%$ respectively.

2) The null hypothesis of ADF is that the series contains a unit root.

3) The null hypothesis of PP is that the series contains a unit root.

\subsubsection{Panel Unit Root}

To verify whether all variables in the panel dataset are integrated in the same order, we employ Im et al. (2003), Levin et al. (2002), and Maddala and Wu (1999) tests. Results are presented in Table 2. All variables are found to be mostly non-stationary at level and stationary at the first difference. 
Table 2. Panel Unit Root Tests

\begin{tabular}{|c|c|c|c|c|c|c|}
\hline \multirow[t]{2}{*}{ Variables } & \multicolumn{2}{|c|}{$\begin{array}{l}\text { Common Root: } \\
\text { Levin et al. (2002) }\end{array}$} & \multicolumn{2}{|c|}{$\begin{array}{c}\text { Individual Root: Im } \\
\text { et al. (2003) }\end{array}$} & \multicolumn{2}{|c|}{$\begin{array}{l}\text { Individual Root: } \\
\text { Maddala and Wu } \\
\text { (1999) }\end{array}$} \\
\hline & C & C\&T & $\mathrm{C}$ & C\&T & $\mathrm{C}$ & C\&T \\
\hline $\operatorname{lnpcgdp}$ & 4.413 & 2.192 & 7.405 & 3.303 & 1.068 & 3.317 \\
\hline$\Delta \operatorname{lnpcgdp}$ & $-2.009^{* *}$ & $-2.071^{* *}$ & $-4.212^{* * *}$ & $-5.069^{* * *}$ & $39.686^{* * *}$ & $44.119^{* * *}$ \\
\hline Lncapy & -1.461 & -1.800 & -0.197 & -0.385 & 13.434 & 11.803 \\
\hline$\Delta l n c a p y$ & $-6.313^{* * *}$ & $-5.950^{* * *}$ & $-7.394^{* * *}$ & $-6.546^{* * *}$ & $68.336^{* * *}$ & $55.871^{* * *}$ \\
\hline Lnaidy & -1.211 & -1.134 & -0.793 & -1.561 & 15.549 & $12.109^{* *}$ \\
\hline$\Delta l n a i d y$ & $-8.657^{* * *}$ & $-7.433^{* * *}$ & $-9.285^{* * *}$ & $-8.308^{* * *}$ & $88.649^{* * *}$ & $73.076^{* * *}$ \\
\hline Lntray & 1.034 & 1.062 & 1.010 & 0.645 & 10.704 & 7.231 \\
\hline$\Delta$ lntray & $-5.884^{* * *}$ & $-5.164^{* * *}$ & $-5.504^{* * *}$ & $-4.428^{* * *}$ & $49.116^{* * *}$ & $37.376^{* * *}$ \\
\hline
\end{tabular}

Notes: 1) ${ }^{* * *}, * *$ and $*$ imply significance levels at $1 \%, 5 \%$ and $10 \%$ respectively.

2) The null hypothesis of Levin et al. is that the series contains a unit root.

3) The null hypothesis of Im et al. is that the series contains a unit root.

4) The null hypothesis of Maddala and $\mathrm{Wu}$ is that the series contains a unit root.

\subsection{Techniques of Cointegration}

\subsubsection{Time Series Cointegration}

To establish long-run relationships between variables, a number of approaches such that the vector autoregresssion (VAR) and structural econometric modeling are available in the existing literature. While the VAR emphasizes on the importance of model selection and data-based criteria, structural econometric modeling mainly focuses on the role of economic theory in designing the econometric model. Cointegration analysis can be considered as an effective reconciliation of both these approaches. Additionally, dynamic relationships in a cointegration framework are not subject to prior restrictions.

In this study, we attempt to identify if there exists cointegrating relationships between variables. This involves examining the residuals from the cointegrating regression and, in particular, testing null hypothesis of no cointegration and the alternative hypothesis of existence of cointegration. For country-specific studies, we employ Johansen cointegration procedure, which is based on Maximum Likelihood (ML) and the assumption of multivariate normality. By producing a table of statistics regarding null and alternative hypotheses and critical values for various tests, Johansen's technique shows how to estimate different cointegrating relationships. On the basis of these results, it is possible to specify the number of cointegrating equations. We also test hypotheses using likelihood ratio test (comparing restricted and unrestricted estimators). It appears that the limiting distribution under the null hypothesis is $\chi^{2}$ - same as in conventional asymptotic analysis.

Cointegration generally refers to the linear combination of nonstationary variables. The primary objective of Johansen cointegration procedure is to find out the number of 
cointegrating vectors in the linear system. If the number of cointegrating vector $(r)$ is zero, then we can assume that there is no long run relationship among variables. This procedure generally produces two types of likelihood test statistics- the Trace test $\left(\lambda_{\text {trace }}\right)$ and the Maximum eigenvalue test $\left(\lambda_{\max }\right)$. Theoretically, $\lambda_{\text {trace }}$ and $\lambda_{\max }$ can produce contradictory results (Johansen and Juselius, 1990). The hypothesis that there is at least one cointegrating vector in our sample data set cannot be rejected if both $\lambda_{\text {trace }}$ and $\lambda_{\max }$ are found to be significant.

\subsubsection{Panel Cointegration}

As opposed to some traditional pooling techniques, economists often use panel cointegration technique to establish the long run equilibrium. One of the major advantages of panel cointegration is to control for the country size. Additionally, panel estimation procedure can also solve the problem of heterogeneity. Pedroni (1999) approach is particularly popular for taking heterogeneity into consideration as it uses specific parameters that can vary across countries in the sample. This test is based on an examination of the residual of a spurious regression performed using I(1) variables. The residual should be $\mathrm{I}(0)$ if the variables are cointegrated.

For the residual based Pedroni (1999) test, we first compute the residuals of the hypothesized cointegrating regression:

$$
(\ln p c g d p)_{i, t}=\alpha_{i}+\beta_{i}(\ln \text { aidy })_{i, t}+\delta_{i}(\ln c a p y)_{i, t}+\gamma_{i}(\ln t r a y)_{i, t}+\varphi_{i} t+\varepsilon_{i, t}, \text { for } i=1, \ldots, N
$$

$t=1, \ldots, T$, where $N$ is the number of countries in the panel and $T$ is the number of observations over time. The estimated residual becomes:

$$
\widehat{\varepsilon}_{i t}=\widehat{\rho}_{i} \widehat{\varepsilon}_{i t-1}+\widehat{v}_{i t}
$$

Assuming the null hypothesis of no cointegration, the above mentioned residual becomes I(1), where, $\rho_{i}=1$. Pedroni (1999) reported two alternative hypothesis: the homogeneous alternative, $\left(\rho_{i}=\rho\right)<1$, which is also known as within-dimension test, and heterogeneous alternative $\rho_{i}<1$ for all $\mathrm{i}$, which is also known as between-dimension or group statistics.

Following panel cointegration, and using appropriate mean and variance, the test statistics under Pedroni test are asymptotically and normally distributed as; $\frac{\theta_{N T}-\mu \sqrt{N}}{\sqrt{v}} \Rightarrow N(0,1)$, where $\theta_{N T}$ represents the corresponding form of test statistics with respect to $\mathrm{N}$ and $\mathrm{T}$. $\mu$ and $v$ are the mean and variance, numerical values of which depend upon the presence of a constant, time trend, and the number of regressors in the cointegration test regression (Pedroni, 1999). 


\section{Results}

\subsection{Johansen Cointegration Results}

Table 3 presents the results of Johansen coingration procedure. The lag lengths are selected using AIC and SBC criteria. Our general results suggest that there exists cointegrating relationships between variables in all five South Asian countries. Therefore, based on Trace test and Maximum eigenvalue test statistics, we cannot reject the hypothesis that there exists at least one cointegrating vector in all these countries. Moreover, the eigenvalue drops fairly sharply for all countries- suggesting that a stable long run relationship exists in all five countries in our specified model.

Table 3 also represents long run estimated coefficient of variables for all five countries. We find that foreign aid has a positive and significant impact on the normalized log real GDP per capita in Bangladesh, Nepal, Pakistan and Sri Lanka. On average, aid does not have any significant impact on growth of real GDP per capita in India. Not surprisingly, given the size of the economy, the aid to GDP ratio becomes meager for India. Hence, the very nature and size of Indian economy may be attributed to an insignificant aid-GDP nexus in India.

Table 3. Results from Cointegration Tests for Individual Country

\begin{tabular}{c|c|c|c|c}
\hline \multirow{2}{*}{ Null Hypothesis } & $\begin{array}{c}\text { Alternative } \\
\text { Hypothesis }\end{array}$ & Eigenvalue & $\lambda_{\max }$ & $\lambda_{\text {trace }}$ \\
\hline \multicolumn{4}{c}{ Bangladesh } \\
\hline $\mathrm{r}=0$ & $\mathrm{r}=1$ & 0.76 & $78.14^{* * * *}$ & $54.08^{* * *}$ \\
$\mathrm{r} \leq 1$ & $\mathrm{r}=2$ & 0.38 & 34.28 & 32.14 \\
$\mathrm{r} \leq 2$ & $\mathrm{r}=3$ & 0.35 & 13.33 & 18.22 \\
$\mathrm{r} \leq 3$ & $\mathrm{r}=4$ & 0.15 & 4.89 & 4.89
\end{tabular}

Long Run Equation: $\operatorname{lnp} c g d p=0.12($ lnaidy $) * * *+0.70($ lncapy $) * *-0.07($ lntray $)-07.28 t$

Both $\lambda_{\max }$ and $\lambda_{\text {trace }}$ indicate one cointegrating equation.

\begin{tabular}{l|l|c|c|c}
\hline \multicolumn{5}{c}{ India } \\
\hline $\mathrm{r}=0$ & $\mathrm{r}=1$ & 0.78 & 27.52 & $67.89^{* * *}$ \\
$\mathrm{r} \leq 1$ & $\mathrm{r}=2$ & 0.45 & 24.01 & $40.36^{* * *}$ \\
$\mathrm{r} \leq 2$ & $\mathrm{r}=3$ & 0.30 & 10.80 & 16.35 \\
$\mathrm{r} \leq 3$ & $\mathrm{r}=4$ & 0.09 & 5.55 & 9.16
\end{tabular}

Long Run Equation: $\ln p c g d p=-0.71($ lnaidy $)+0.14(\text { lncapy })^{* * *}+0.66(\text { lntray })^{* *+04.86 t}$

$\lambda_{\text {trace }}$ indicates two cointegrating equations. 
Table 3 (cont.). Results from Cointegration Tests for Individual Country

\begin{tabular}{l|c|c|c|c}
\hline \multirow{2}{*}{ Null Hypothesis } & $\begin{array}{c}\text { Alternative } \\
\text { Hypothesis }\end{array}$ & Eigenvalue & $\lambda_{\max }$ & $\lambda_{\text {trace }}$ \\
\hline \multicolumn{4}{c}{ Nepal } \\
\hline $\mathrm{r}=0$ & $\mathrm{r}=1$ & 0.68 & $35.38^{* * *}$ & $65.03^{* * *}$ \\
$\mathrm{r} \leq 1$ & $\mathrm{r}=2$ & 0.40 & 15.87 & 29.65 \\
$\mathrm{r} \leq 2$ & $\mathrm{r}=3$ & 0.24 & 8.69 & 13.78 \\
$\mathrm{r} \leq 3$ & $\mathrm{r}=4$ & 0.15 & 5.09 & 5.09
\end{tabular}

Long Run Equation: $\ln p c g d p=0.24(\text { lnaidy })^{* *}+1.18(\text { lncapy })^{* *}+7.07($ lntray $)+0.18 \mathrm{t}$

Both $\lambda_{\max }$ and $\lambda_{\text {trace }}$ indicate one cointegrating equation.

\begin{tabular}{l|l|c|c|c}
\hline \multicolumn{5}{c}{ Pakistan } \\
\hline $\mathrm{r}=0$ & $\mathrm{r}=1$ & 0.54 & 23.85 & $63.84^{* * *}$ \\
$\mathrm{r} \leq 1$ & $\mathrm{r}=2$ & 0.48 & 20.29 & $39.99^{* *}$ \\
$\mathrm{r} \leq 2$ & $\mathrm{r}=3$ & 0.38 & 14.59 & 19.69 \\
$\mathrm{r} \leq 3$ & $\mathrm{r}=4$ & 0.15 & 5.09 & 5.10
\end{tabular}

Long Run Equation: $\ln p c g d p=0.05(\text { lnaidy })^{*}-0.04(\text { lncapy })^{*}+0.56($ Intray $) * *+1.52 \mathrm{t}^{* *}$

$\lambda_{\text {trace }}$ indicates two cointegrating equations.

\begin{tabular}{l|l|c|c|c}
\hline \multicolumn{5}{c}{ Sri Lanka } \\
\hline $\mathrm{r}=0$ & $\mathrm{r}=1$ & 0.71 & $38.76^{* * *}$ & $79.80^{* * *}$ \\
$\mathrm{r} \leq 1$ & $\mathrm{r}=2$ & 0.51 & 21.96 & $41.04^{* *}$ \\
$\mathrm{r} \leq 2$ & $\mathrm{r}=3$ & 0.41 & 16.57 & 19.08 \\
$\mathrm{r} \leq 3$ & $\mathrm{r}=4$ & 0.08 & 2.51 & 2.51
\end{tabular}

Long Run Equation: $\ln p c g d p=0.21($ lnaidy $)+1.67($ lncapy $)-0.28($ lntray $)-0.72 t^{*}$

$\lambda_{\text {trace }}$ indicates two cointegrating equations and $\lambda_{\max }$ indicates one cointegrating equation.

Note: $\quad * * *, * *$ and $*$ imply significance levels at $1 \%, 5 \%$ and $10 \%$ respectively.

Other results indicate that investment has a positive and significant effect on growth of real GDP per capita for all countries but Pakistan. Trade openness is positively (and statistically significantly) related to real GDP per capita in India, Nepal and Pakistan but negatively related in Bangladesh and Sri Lanka.

Most of the variables are cointegrated at different levels for different countries. Therefore, the long run equilibrium relationship holds and variables cannot move independently of each other. In Johansen method, we treat all variables symmetrically. As we are assuming that variables are jointly determined and not sure how to disentangle the interdependence among them, using a cointegration approach (particularly Johansen approach) is advantageous.

\subsection{Speed of Short-Run Adjustments}

The two-step approach of the error-correction model uses results from cointegrating regression to estimate the error correction term. Johansen cointegration directly works with ECM and allows a framework to introduce sufficient lags for a well-behaved disturbance 
term. After Johansen method is used, we concentrate on a particular equation in the ECM. To estimate the ECM for inferential and interpretive purposes, selection of most appropriate numbers of differenced, and lag lengths are important. Enders (2010) and Davidson and MacKinnon (2004) suggest that a likelihood ratio where, a $\chi^{2}$ test is used to compare a complete model versus a restricted model. Several researchers have opted to use one (or more) of the information criteria, such as, Akaike's Information Criterion (AIC) and Schwarz's Information Criterion (SIC) etc. Based on our theoretical model, and following Irandoust and Ericsson (2004), this study uses SIC to determine the lag length for ECM model.

Table 4 shows the results of the error correction models of all five South Asian countries for real GDP per capita growth. The error correction coefficients are negative and statistically significant for all countries but India. The significant error correction terms are $-0.194,-0.135$, $-0.264,-0.127$ for Bangladesh, Nepal, Pakistan and Sri Lanka respectively. Therefore, in Bangladesh, due to one percent deviation from the long run equilibrium, the growth of real GDP per capita is corrected by $19.4 \%$ per year. In other words, the long run equilibrium will be reached in approximately five and half years in Bangladesh. Similarly, growth of real GDP per capita is corrected by $13.5 \%$ per year in Nepal, $26.4 \%$ is Pakistan and $12.7 \%$ per year in Sri Lanka. Thus, real GDP per capita reaches the long run equilibrium in approximately seven and half years in Nepal, four years in Pakistan and eight years in Sri Lanka. The speed of adjustment in India seems to be low and insignificant. Short run coefficients for other variables produce mixed results in our study.

Table 4. Results from the Error Correction Procedure

\begin{tabular}{|c|c|c|c|c|c|}
\hline Variables & Bangladesh & India & Nepal & Pakistan & Sri Lanka \\
\hline & -0.194 & -0.029 & -0.135 & -0.264 & -0.127 \\
\hline \multirow[t]{2}{*}{$E C M_{t-1}$} & $(-2.73)$ & $(-0.401)$ & $(-2.41)$ & $(-2.63)$ & $(-1.66)$ \\
\hline & 0.487 & 0.054 & -0.316 & 0.160 & 0.042 \\
\hline \multirow[t]{2}{*}{$\Delta \operatorname{lnpcgdp} p_{t-1}$} & $(2.41)$ & $(0.23)$ & $(-1.69)$ & $(0.62)$ & $(0.20)$ \\
\hline & 0.513 & -0.020 & -0.484 & 0.514 & -0.043 \\
\hline \multirow{2}{*}{$\Delta \operatorname{lnpcgd} p_{t-2}$} & $(2.36)$ & $(-0.09)$ & $(-2.63)$ & $(1.50)$ & $(-0.19)$ \\
\hline & 0.019 & 0.002 & 0.004 & 0.002 & 0.002 \\
\hline \multirow[t]{2}{*}{$\Delta \operatorname{lnaid}_{t-1}$} & $(0.01)$ & $(0.08)$ & $(1.22)$ & $(1.06)$ & (1.19) \\
\hline & -0.041 & 0.008 & 0.002 & 0.000 & 0.003 \\
\hline \multirow[t]{2}{*}{$\Delta \operatorname{lnaidy}_{t-2}$} & $(-0.33)$ & $(0.40)$ & $(0.70)$ & $(0.29)$ & $(2.20)$ \\
\hline & 0.078 & -0.004 & -0.026 & -0.085 & 0.102 \\
\hline \multirow[t]{2}{*}{$\Delta \operatorname{lncapy}_{t-1}$} & $(1.46)$ & $(-0.50)$ & $(-0.35)$ & $(-0.88)$ & $(2.60)$ \\
\hline & 0.039 & 0.000 & -0.098 & -0.128 & -0.003 \\
\hline \multirow[t]{2}{*}{$\Delta \operatorname{lncapy}_{t-2}$} & (1.07) & $(0.04)$ & $(-1.57)$ & $(-1.60)$ & $(-0.06)$ \\
\hline & -0.052 & 0.226 & 0.042 & 0.017 & -0.203 \\
\hline \multirow[t]{2}{*}{$\Delta \operatorname{lntray}_{t-1}$} & $(-1.72)$ & $(2.66)$ & $(0.60)$ & $(0.33)$ & $(-2.83)$ \\
\hline & -0.045 & 0.060 & 0.003 & 0.087 & 0.044 \\
\hline$\Delta \operatorname{lntray}_{t-2}$ & $(-1.55)$ & $(0.52)$ & $(0.05)$ & $(1.74)$ & $(0.60)$ \\
\hline
\end{tabular}

Note: $t$-statistics are in the parenthesis 


\subsection{Panel Cointegration Results}

As a pre-test for the cointegration analysis, we first investigate panel-nonstationarity among variables. After inspection of the data, we include both constant and trend. We use SIC to decide the optimal lag length. Following non-stationary in panel unit root test, we conduct panel cointegration test.

Table 5 reports the outcome of Pedroni (1999) cointegration tests. We report seven panel-cointegration test statistics under appropriate standardization. First, large positive $v$ value, which is greater than the critical value at the 5 percent level of 1.64 , leads us to a rejection of the null hypothesis of no cointegration. We also report three within-dimension-based; panel $\rho$, panel pp, and panel ADF statistics, and three between-dimension-based; group $\rho$, group pp, and group ADF statistics. Theoretically, between-dimension statistics are group mean approach of the within dimension based statistics. According to Gutierrez (2003) the group $\rho$ statistic has the best power among the test statistics of Pedroni (1999). Results of all within-dimension and between-dimension based test, but group ADF, are statistically significant, which reject the null hypothesis of no cointegration.

Table 5. Results from the Panel Cointegration

\begin{tabular}{ccc}
\hline Estimates & Statistic & Probabilities \\
\hline Panel $v$-statistic & 2.775 & 0.040 \\
Panel $\rho$-statistic & -2.316 & 0.010 \\
Panel $P P$ statistic & -2.780 & 0.002 \\
Panel $A D F$ statistic & -1.961 & 0.025 \\
\hline Alternative Hypothesis: Individual AR coefficient & \\
\hline Group $\rho$-statistic & -2.091 & 0.018 \\
Group $P P$ statistic & -3.569 & 0.002 \\
Group $A D F$ statistic & -1.291 & 0.118 \\
\hline
\end{tabular}

Therefore, we may conclude that, in panel structure, the variables under investigation are cointegrated. It should be noted that Pedroni test allows us to test whether the variables in the panel are cointegrated, however, it cannot provide estimation for long run relationship and speed of adjustment towards the long run (Murthy, 2007).

\section{Conclusion}

Effective use of external resources creates the possibility of accelerating economic growth in developing countries (Chenery and Strout, 1966). Because of the recent global recession, there has been a significant withdrawal of capital from developing economies. The other source of external resource, such as remittances has also gone down as migrants are returning from host countries (Birdsall, 2009). In such a situation, foreign aid could be the only source of external resources to fill the savings and foreign exchange constraints that developing countries face. The effectiveness of foreign aid will depend on its ultimate relationship with economic growth. 
In this research endeavor we attempted to determine the effectiveness of aid in increasing growth in real GDP per capita in South Asia. To do so, we estimated aid-growth relationship by using different recently developed time series and panel cointegration techniques for five South Asian countries over the period 1976 to 2008. Our data set included following countries: Bangladesh, India, Nepal, Pakistan and Sri Lanka. Results indicate that, indeed, there exist long run relationships between natural log of foreign aid as a percentage of GDP and natural log of real GDP per capita in most countries in South Asia. More specifically, foreign aid has a positive and significant impact on real GDP per capita growth in Bangladesh, Nepal, Pakistan and Sri Lanka. However, there is no indication that this relationship exists for India. Aid does not have any significant impact on growth of real GDP per capita in India. This result is not surprising. Given the large size of Indian economy, the ratio of ODA and GDP is too small to exhibit any significant impact on Indian growth rate. For other variables, investment is found to be positive and significant in all South Asian countries except Pakistan. Trade openness (measured as total trade/GDP) seems to a have positive and long run relationship with real GDP per capita growth for India, Nepal and Pakistan but a negative relationship for Bangladesh and Sri Lanka.

A key objective of this investigation was to determine the short run speed of adjustment of variables towards their long run equilibrium. We found different speed of adjustment for different countries. Our results suggest that due to one percent deviation from the long run equilibrium, the growth of real GDP per capita is corrected in approximately five and half years in Bangladesh, seven and half years in Nepal, four years in Pakistan and eight years in Sri Lanka. The speed of adjustment in India was found to be insignificant.

Our results provide strong evidence that aid has influenced long run growth in South Asia over the period 1976 to 2008 . The positive relationship between aid and growth thus indicate that foreign aid can be used as an important tool in achieving desired rate of growth in these countries. In fact, given the strong likelihood of a sharp decline in remittance flows because of the recent recession, coupled with limited access to the global capital market, foreign aid seems to be the only type of financial flow that can play an important role in boosting economic growth in this region. We also found investment to be positive and significant in all five South Asian countries. Therefore, it seems to suggest that foreign aid augments domestic resources and helps to fill up the foreign exchange gap, helps economies to purchase the needed capital and intermediate goods to achieve the quality of investment.

From our empirical investigation, we observe a long run aid-growth nexus in South Asia. The implication of these results is that over the long run, South Asia has been successful in utilizing the foreign aid in boosting economic growth. However, to consolidate this process and to ensure sustained growth, this region has to address emerging challenges in many ways. To maintain and accelerate growth, South Asian countries should formulate policies to intensify the allocation of foreign resources into investment projects. Such policies may not only include investment on consumer goods and services, but also include investment of infrastructure and transportation system. Institutional weakness in these countries may pose a limit to the growth. Developing strategies to deal with institutional bottlenecks such as, inadequate electricity and infrastructure and reforms in the banking sector are crucial. 
While growth in South Asia is found to be spurred by foreign aid, however, the effectiveness of foreign aid to spur economic growth might be conditional on governance and institutional quality. Over the recent years, different variables for economic policy and the institutional quality are included in aid-growth regressions (Boone 1996, Burnside and Dollar 2000). These studies have received particular attention in the academia. It must be admitted that these studies have immense contributions in understanding the aid-growth nexus. However, time series data on policy variables are not available for South Asian countries. Moreover, the incorporation of governance in the growth equation can possibly introduce the problem of multicollinearity, since aid and aid governance can be highly correlated (Fenny, 2005). Hence, relying on readily available time series data of the macroeconomic variables and following modified version of first generation theoretical models of aid-growth relationship (those mentioned in the theoretical literature review section) appears to be the best option for our investigation.

\section{Acknowledgement}

Authors thank John Loxley and John Serieux of University of Manitoba and anonymous referees for their valuable comments and suggestions.

\section{References}

Asteriou, D. (2009). Foreign Aid and Economic Growth: New Evidence from a Panel Data Approach for Five South Asian Countries. Journal of Policy Modeling, 31, 155-161.

Azam, J. P. et al. (1999). Aid Dependence Reconsidered. World Bank Policy Paper, No. 2144.

Bacha, E. L. (1990). A Three-Gap Model of Foreign Aid Transfers and the GDP Growth Rate in Developing Countries. Journal of Development Economics, 32, 279-296.

Bauer, P. T. (1971). Dissent on Development. London: Weidenfield and Nicholson.

Birdsall, N. (2009). How to Unlock the \$1 Trillion that Developing Countries Urgently Need to Cope with the Crisis. Center for Global Development Notes, February 17. [Online] Available: http://www.cgdev.org/content/general/detail/1421143/ (March 20, 2010)

Blackburne III, E. F., \& Frank, M. W. (2007). XTPMG: Stata Module for Estimation of Nonstationary Heterogeneous Panels. The STATA Journal, 7(2), 197-208.

Boone, P. (1996). Politics and the Effectiveness of the Foreign Aid. European Economic Review, 40, 289-329.

Burke, P. J., \& Ahmadi-Esfahani, F. Z. (2006). Aid and Growth: A Study of South East Asia. Journal of Asian Economics, 17(2), 350-362.

Burnside, C., \& Dollar, D. (2000). Aid, Policies and Growth. American Economic Review, 90, 847-868.

Chenery, H. B., \& Strout, A. M. (1966). Foreign Assistance and Economic Development, American Economic Review, 56(4), 679-733. 
Davidson, R., and MacKinnon, J. G. (2003). Econometric Theory and Method. Don Mills: Oxford University press.

Dhakal, D. et al. (1996). Foreign Aid, Economic Growth and Causality, Rivista Internazionale di Scienze Economiche e Commerciali, 43, 597-606.

Enders, W. (2010). Applied Econometric Time Series. ( ${ }^{\text {rd }}$ Edition). Hoboken: Wiley.

Fenny, S. (2005). The Impact of Foreign Aid on Economic Growth in Papua New Guinea. The Journal of Development Studies, 41(6), 1092-1117.

Friedman, M. (1958). Foreign Aid. Yale Review, 47, 500-516.

Giles, J. A. (1994). Another Look at the Evidence of Foreign Aid Led Economic Growth. Applied Economic Letters, 1, 194-199.

Gounder, R. (2001). Aid-Growth Nexus: Empirical Evidence from Fiji. Applied Economics, 33(8), 1009-1019.

Griffin, K.B., \& Enos, J. L. (1970). Foreign Assistance: Objectives and Consequences. Economic Development and Cultural Change, 18(3), 313-327.

Griffin, K.B. (1970). Foreign Capital, Domestic Savings and Economic Development. Bulletin of the Oxford University Institute of Economics and Statistics, 32(2), 99-112.

Gutierrez, L. (2003). On the Power of Panel Cointegration Test: A Monte Carlo Comparison. Economic Letters, 80(1), 105-111.

Hansen, H., \& Tarp, F. (2000). Policy Arena: Aid Effectiveness Disputed. Journal of International Development, 12, 375-398.

Hatemi-J, A., \& Irandoust, M. (2005). Foreign Aid and Economic Growth: New Evidence from Panel Cointegration, Journal of Economic Development, 30(1), 1-10.

Im, K. S. et al. (2003). Testing for Unit Roots in Heterogeneous Panels. Journal of Econometrics, 115, 53-74.

Irandoust, M., \& Ericsson, J. (2005). Foreign Aid, Domestic Savings and Growth in LDCs: An Application of Likelihood-based Panel Cointegration. Economic Modelling, 22, 616-627.

Islam, A. (1992). Foreign Aid and Economic Growth: An Econometric Study of Bangladesh. Applied Economics, 24, 541-544.

Johansen, S., \& Juselius, K. (1990). Maximum Likelihood Estimation and Inference on Cointegration. Oxford Bulletin of Economics and Statistics, 52, 169-210.

Johansen, S. (1991). Estimation and Hypothesis Testing of Cointegration Vectors in Gaussian Vector Autoregressive Models, Econometrica, 59(6), 1551-1580.

Khan, N. Z., \& Rahim, E. (1993). Foreign Aid, Domestic Savings and Economic Growth (Pakistan: 1960-1988). The Pakistan Development Review, 32(4), 1157-1164. 


\section{Al Macrothink}

Research in Applied Economics

ISSN 1948-5433

2011, Vol. 3, No. 1: E3

Levin, A. et al. (2002). Unit Root Tests in Panel Data: Asymptotic and Finite-Sample Properties. Journal of Econometrics, 108(1), 1-24.

Levy, V. (1988). Aid and Growth in Sub-Saharan Africa: The Recent Experience. European Economic Review, 32, 1777-1795.

Loxley, J., \& Sackey, H.A. (2008). Aid Effectiveness in Africa. African Development Review, 20(2), 163-199.

Maddala, G. S., \& Wu, S. (1999). A Comparative Study of Unit Root Tests with Panel Data and a New Simple Test. Oxford Bulletin of Economics and Statistics, Special Issue, 631-652.

Mahmood, Z. (1993). Comment on Foreign Aid, Domestic Savings and Economic Growth (Pakistan: 1960-1988). The Pakistan Development Review, 32(4), 1165-1167.

Mallik, G. (2008). Foreign Aid and Economic Growth: A Cointegration Analysis of the Six Poorest African Countries. Economic Analysis and Policy, 38(2), 251-260, [Online] Avaialble: http://www.eap-journal.com.au/vol_38_iss_2.php.

Mbaku, J. M. (1993). Foreign Aid and Economic Growth in Cameroon. Applied Economics, $25,1309-1314$.

Murthy, N. R. V. (2007). Panel Cointegration Analysis: An Empirical Example, in Cointegration for the Applied Economist. In Rao, B. (ed.) Cointegration for the Applied Economics, (Second Edition), 222-256.

Newlyn, T. W. (1973). The Effect of Aid and Other Resource Transfers on Savings and Growth in Less Developed Countries: A Comment. The Economic Journal, 83(331), 867-869.

Otim, S. (1996). Foreign Aid and Government Fiscal Behavior in Low Income South Asian Countries. Applied Economics, 28(8), 927-933.

Pallage, S., \& Robe, M. A. (2003). On the Welfare Cost of Economic Fluctuations in Developing Countries. International Economic Review, 44(2), 677-698.

Papanek, G. F. (1972). The Effect of Aid and Other Resource Transfers on Savings and Growth in Less Developed Countries. The Economic Journal, 82(327), 934-950.

Pedroni, P. (1999). Critical Values for Cointegration Tests in Heterogeneous Panels with Multiple Regressors. Oxford Bulletin of Economics and Statistics, 61, 653-670.

Perron, P. (1989). The Great Crash, the Oil Price Shock and the Unit Root Hypothesis. Econometrica, 57(6), 1361-1401.

Pesaran, M. H. et al. (1999). Pooled Mean Group Estimation of Dynamic Heterogeneous Panels. Journal of American Statistical Association, 94(446), 621-634.

Radelet, S. (2006). A Premier on Foreign Aid. Working Paper. 92, Center for Global Development. 
Rahman, A. (1967). The Welfare Economics of Foreign Aid. Pakistan Development Review, 7(2), 141-159.

Shabbir, T., \& Mahmood, A. (1992). The Effects of Foreign Private Investment and Economic Growth in Pakistan. The Pakistan Development Review, 31(4), 831-841.

Vasudeva, N. R. et al. (1994). Foreign Aid and Economic Growth in Cameroon: Evidence from Cointegration Tests. Applied Economic Letters, 1, 161-163.

Weisskopf, T. E. (1972). The Impact of Foreign Capital Inflow on Domestic Savings in Underdeveloped Countries. Journal of International Economics, 2, 25-38.

\section{Copyright Disclaimer}

Copyright reserved by the author(s).

This article is an open-access article distributed under the terms and conditions of the Creative Commons Attribution license (http://creativecommons.org/licenses/by/3.0/). 